\section{Pacific Northwest}

National Laboratory

Operated by Battelle for the

U.S. Department of Energy

\title{
Area Monitoring Dosimeter Program for the Pacific Northwest National Laboratory: Results for CY 2002
}

\author{
S.R. Bivins \\ G.A. Stoetzel
}

June 2003

Prepared for the U.S. Department of Energy under Contract DE-AC06-76RL01830

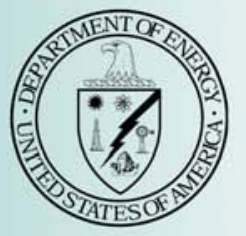




\title{
DISCLAIMER
}

This report was prepared as an account of work sponsored by an agency of the United States Government. Neither the United States Government nor any agency thereof, nor Battelle Memorial Institute, nor any of their employees, makes any warranty, express or implied, or assumes any legal liability or responsibility for the accuracy, completeness, or usefulness of any information, apparatus, product, or process disclosed, or represents that its use would not infringe privately owned rights. Reference herein to any specific commercial product, process, or service by trade name, trademark, manufacturer, or otherwise does not necessarily constitute or imply its endorsement, recommendation, or favoring by the United States Government or any agency thereof, or Battelle Memorial Institute. The views and opinions of authors expressed herein do not necessarily state or reflect those of the United States Government or any agency thereof.

\author{
PACIFIC NORTHWEST NATIONAL LABORATORY \\ operated by \\ BATTELLE \\ for the \\ UNITED STATES DEPARTMENT OF ENERGY \\ under Contract DE-AC06-76RL01830
}

Printed in the United States of America

Available to DOE and DOE contractors from the

Office of Scientific and Technical Information,

P.O. Box 62, Oak Ridge, TN 37831-0062;

ph: (865) 576-8401

fax: (865) 576-5728

email: reports@adonis.osti.gov

\author{
Available to the public from the National Technical Information Service, \\ U.S. Department of Commerce, 5285 Port Royal Rd., Springfield, VA 22161 \\ ph: (800) 553-6847 \\ fax: $(703) 605-6900$ \\ email: orders@ntis.fedworld.gov \\ online ordering: http://www.ntis.gov/ordering.htm \\ This document was printed on recycled paper.
}

$(8 / 00)$ 


\section{Summary}

In January 1993, Pacific Northwest National Laboratory (PNNL) established an area monitoring dosimeter program in accordance with Article 514 of the U.S. Department of Energy (DOE) Radiological Control Manual (RCM). The purpose of this program was to minimize the number of areas requiring issuance of personnel dosimeters and to demonstrate that doses outside Radiological Buffer Areas are negligible. In accordance with 10 CFR Part 835.402 (a) (1)-(4) and Article 511.1 of the PNNL

Radiological Control Program Description, personnel dosimetry shall be provided to 1) radiological workers who are likely to receive at least 100 mrem annually and 2) declared pregnant workers, minors, and members of the public who are likely to receive at least 50 mrem annually. Program results for calendar years 1993-2001 confirmed that personnel dosimetry was not needed for individuals located in areas monitored by the program.

Area thermoluminescent dosimeters (TDLs) were placed at 117 locations in PNNL facilities during calendar year 2002. The TLDs were exchanged and analyzed quarterly. All routine area monitoring TLD results were less than 50 mrem annually after correcting for worker occupancy. The results support the

conclusion that personnel dosimeters are not necessary for staff, declared pregnant workers, minors, or members of the public in these monitored areas. 


\section{Contents}

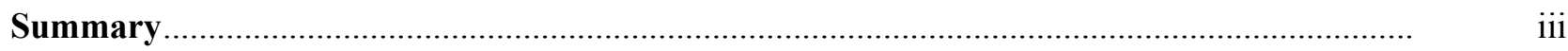

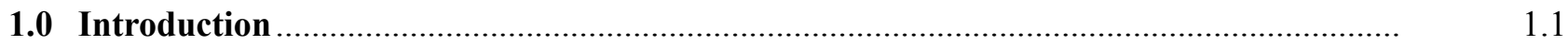

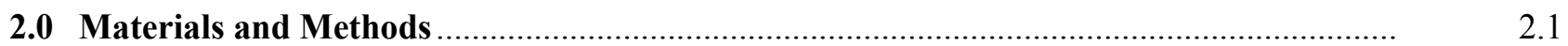

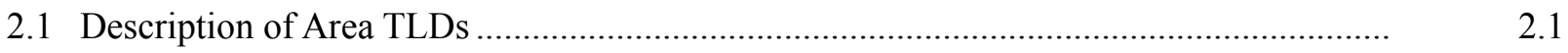

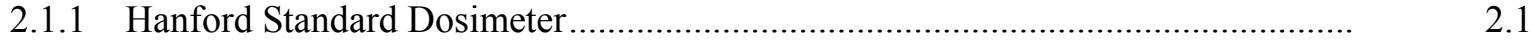

2.1.2 Hanford Combination Neutron Dosimeter ............................................................

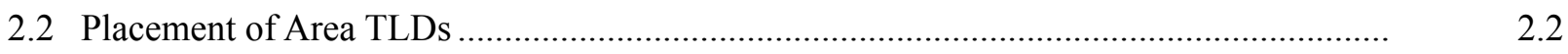

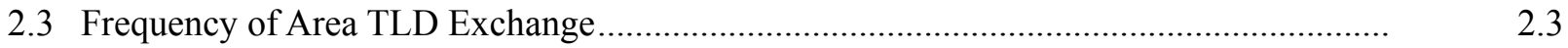

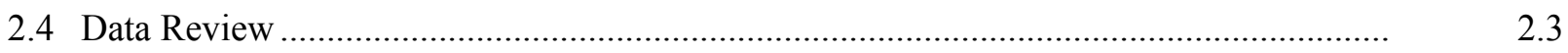

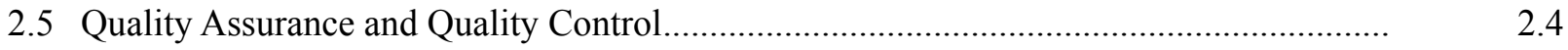

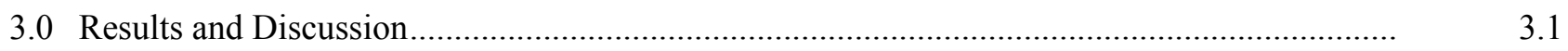

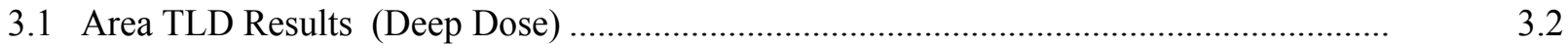

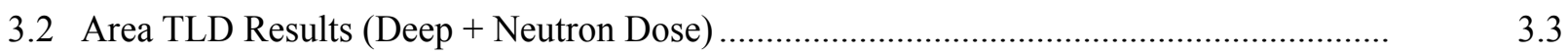

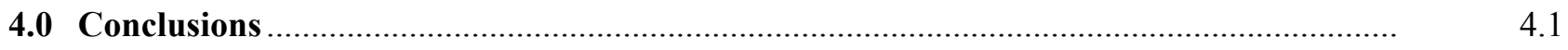

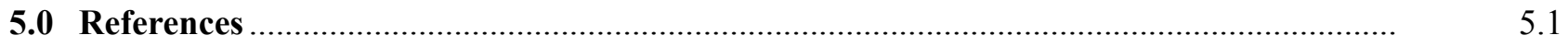

Appendix A - Area TLD - Processing, Calibration, and Dose Assessment .................................. A.1

Appendix B - Locations of Area Monitoring TLDs....................................................................... B.

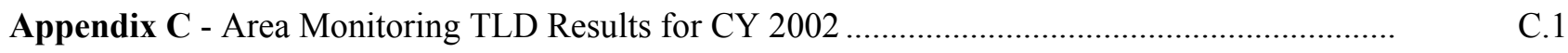




\section{Tables}

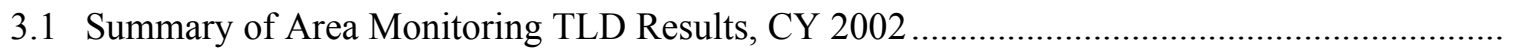

3.2 Estimated Annual Dose to an Individual at Selected Locations, CY 2002 ...................... 3.6

3.3 Comparison of Neutron Doses between Hanford Standard Dosimeters and Hanford

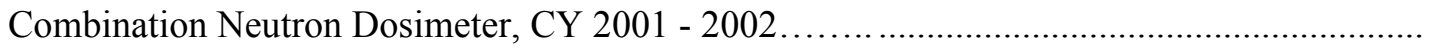

\section{Figures}

3.1 Deep Dose Trend Data, CY 2002 


\subsection{Introduction}

The U.S. Department of Energy Standard on Radiological Control (DOE Standard) (DOE 1999), first issued as the DOE Radiological Control Manual (RCM) in 1992, provides guidelines to assist line managers in meeting their responsibilities for implementing occupational radiological control programs. Article 514 of the DOE Standard, included in the PNNL Radiological Control Program Description, discusses the establishment and maintenance of a comprehensive area monitoring dosimeter program to minimize the number of areas requiring issuance of personnel dosimeters and to demonstrate that doses outside of radiological areas are negligible. This program complies with 10 CFR Part 835.401(a)(3), 401(a)(6), 402(a)(3), 401(a)(4), and 1003(b). As discussed in Article 514 of the PNNL Radiological Control Program Description, area monitoring dosimeters should do the following:

- record and document radiation levels in routinely occupied areas adjacent to areas where radiation or operations with radiation exist (not applicable when the radiation arises solely from low-energy beta sources such as ${ }^{14} \mathrm{C}$ or ${ }^{3} \mathrm{H}$ )

- support dosimetry investigations where personnel express concern about their work environment and exposure to ionizing radiation

- $\quad$ supplement existing monitoring programs in Radiologically Controlled Areas and provide data in the event of an emergency.

In January 1993, Pacific Northwest National Laboratory (PNNL) $)^{(1)}$ established an area monitoring thermoluminescent dosimeter (TLD) program in accordance with Article 514 of the RCM. The program was conducted as outlined by Bivins ${ }^{(2)}$ during calendar years (CY) 1993 and 1994. The program is now implemented according to RCP-5.1.04, "Area Monitoring TLD Program," issued in PNL-MA-266, PNL Radiological Control Implementing Procedures. Program results for previous years are found in Bivins and Stoetzel (1996a, 1996b, 1997, 1998, 1999, 2000, 2001, and 2002). Data from the program was also used to support the PNNL As Low As Reasonably Achievable (ALARA) program.

A description of the materials and methods used in collecting area monitoring TLD data and program results for CY 2002 are presented in this report. Neutron dose readings from the area TLDs are included in Section 3.0. Reporting of neutron dose data was initiated in the CY 1998 report (Bivins and Stoetzel 1999).

(1) The Pacific Northwest National Laboratory is operated for the U.S. Department of Energy by Battelle under Contract DE-AC06-76RL01830. Battelle also owns and operates private facilities near the Hanford Site.

(2) Bivins, S. R. February 24, 1993. Letter Report to D.P. Higby entitled "Area Monitoring Dosimeter." Pacific Northwest National Laboratory, Richland, Washington. 


\subsection{Materials and Methods}

This section provides information on the type of TLDs used in the program, how they were located in the field, and frequency of exchange. Derivation of the investigation level, which triggers an evaluation into the potential cause of a reading, is also provided.

\subsection{Description of Area TLDs}

The Hanford Standard Dosimeter and the Hanford Combination Neutron Dosimeter were used in this program during CY 2002. The Hanford Standard Dosimeter was used at all locations; in addition, the Hanford Combination Neutron Dosimeter was positioned at three locations to better quantify neutron doses.

A brief description of each type of dosimeter is presented below. Appendix A provides a description of TLD processing, calibration, and the dose algorithm used in determining doses.

\subsubsection{Hanford Standard Dosimeter}

The Hanford Standard Dosimeter is accredited by the DOE Laboratory Accreditation Program (DOELAP) and is known commercially as a Harshaw 8825 dosimeter. The dosimeter contains TLD-700 chips in positions one, two, and three and a TLD-600 chip in position four. The TLD-600 chip is neutronsensitive. The chips have thicknesses of $0.38 \mathrm{~mm}\left(100 \mathrm{mg} / \mathrm{cm}^{2}\right)$ in positions one, two, and four, and 0.15 $\mathrm{mm}\left(40 \mathrm{mg} / \mathrm{cm}^{2}\right)$ in position three. The TLD holder is constructed of black plastics with the following filtration:

1. position one $-242 \mathrm{mg} / \mathrm{cm}^{2}$ acrylonitrilebutadienestyrene (ABS) plastic and $91 \mathrm{mg} / \mathrm{cm}^{2}$ copper

2. position two $-1000 \mathrm{mg} / \mathrm{cm}^{2}$ ABS plastic and Teflon ${ }^{\circledR}$

3. position three $-8 \mathrm{mg} / \mathrm{cm}^{2}$ Teflon ${ }^{\circledR}$ and $9 \mathrm{mg} / \mathrm{cm}^{2}$ mylar

4. position four $-240 \mathrm{mg} / \mathrm{cm}^{2} \mathrm{ABS}$ plastic and $463 \mathrm{mg} / \mathrm{cm}^{2}$ tin.

These dosimeters were read for shallow dose, deep dose, neutron dose, and eye dose. Only deep dose and neutron dose readings are discussed in this report.

${ }^{\circledR}$ Teflon is a registered trademark of E. I. Du Pont de Nemours Co., Inc., Wilmington, Delaware. 


\subsubsection{Hanford Combination Neutron Dosimeter}

The Hanford Combination Neutron Dosimeter consists of three components: 1) a beta-photon TLD, 2) an albedo neutron TLD, and 3) two CR-39 track-etch dosimeter foils. Instead of CR-39 track-etch dosimeter foils, the albedo neutron TLD is currently used to assess neutron dose. The beta-photon TLD is a Harshaw 8825 dosimeter. The albedo neutron TLD is a Harshaw 8816 dosimeter, which contains three TLD-600 phosphors and one TLD-700 phosphor. This albedo TLD has the following filter configurations:

- TLD-700 \#1 (tin filters on the front and back)

- TLD-600 \#2 (cadmium filter on front and tin filter on back)

- TLD-600 \#3 (tin filter on front and cadmium filter on back)

- TLD-600 \#4 (tin filters on front and back).

These dosimeters were read for shallow dose, deep dose, neutron dose, and eye dose. Only deep dose and neutron dose readings are discussed in this report.

\subsection{Placement of Area TLDs}

Area TLDs were placed in the following PNNL facilities (DOE-owned, DOE-leased, and Battelle private):

- all 300 Area PNNL facilities where staff worked at least eight hours per month

- all PNNL facilities where staff conducted radiological work (i.e., had a current Radiological Work Permit)

- all PNNL facilities located within $15 \mathrm{~m}(\sim 50 \mathrm{ft})$ of another facility (including those of other Hanford Site contractors) containing a radiological area (indoors or outdoors).

TLDs positioned as such are referred to as "routine" area TLDs in this report. Area TLDs were also positioned in facilities as approved by the Radiological Control organization for special situations such as ALARA evaluations. In this report, these are referred to as "special" area TLDs.

A list of routine area TLD locations is included as Appendix B. There were no special area TLD locations during CY 2002. The number of area TLDs in each facility was determined according to the following criteria:

- at least one area TLD per facility

- one additional area TLD for every 25 staff members in facilities requiring area TLDs but not containing a Radiologically Controlled Area or a radiological area

- one additional area TLD for every 15 staff members in facilities requiring area TLDs and containing a Radiologically Controlled Area or a radiological area. 
Hanford Combination Neutron Dosimeters were positioned as area TLDs at the following three locations to better quantify neutron doses:

- 325 Building, east equipment room on the second floor

- 325 Building, first floor hallway between Rooms 115 and 116

- 326 Building, Room 28B on the second floor.

Additional area TLDs were positioned as determined by the Radiological Control organization.

Each Hanford Standard Dosimeter used as an area TLD was oriented per guidance in PNL-MA-842, Hanford External Dosimetry Technical Basis Manual. If the potential source of exposure was from within the facility, the area TLD was placed on the wall opposite the potential source. If the potential source of exposure was located outside the facility, the area TLD was placed on the inside surface of the exterior wall with the Mylar window facing away from the wall. The TLDs were placed 1 to $2 \mathrm{~m}$ ( 3 to $6 \mathrm{ft}$ ) from the floor, depending on whether staff in the area would be standing or seated.

Each Hanford Combination Neutron Dosimeter used as an area TLD was placed on the front-face of a 5 -gallon carboy filled with water. The neutron portion of the dosimeter was at least $7.5 \mathrm{~cm}$ (3 in) from any edge of the carboy. The physical size and weight of the 5-gallon carboy limited the locations where these dosimeters could be positioned.

Each area TLD was identified with an attached bar code label containing a facility ID (e.g., 337, LOC. 5) and a TLD identification number beginning with the letter " $A$ " to denote an area TLD followed by a four-digit number (e.g., A3014).

\subsection{Frequency of Area TLD Exchange}

All area TLDs were scheduled to be exchanged and analyzed quarterly. The area monitoring TLD procedure allows facility managers to request a special exchange for any TLD in their facilities. The Safety \& Health Manager may also request a special exchange for area TLDs in any facility. Any area TLD changed out was immediately replaced with another area TLD unless the area TLD location was being discontinued.

\subsection{Data Review}

Any area TLD results greater than or equal to $40 \mathrm{mrem}$ in a quarter were investigated. This action level was established to ensure that an individual would not likely receive more than 50 mrem annually (the trigger level for requiring personnel dosimetry for declared pregnant workers, minors, and members of the public). The investigation level of 40 mrem per quarter was derived by dividing the $50 \mathrm{mrem}$ annual limit by four and adjusting for worker occupancy. 
The area TLDs were exposed for approximately $8760 \mathrm{~h}$ annually; individual occupancy was assumed to be $2000 \mathrm{~h}(8 \mathrm{~h} / \mathrm{d}, 5 \mathrm{~d} / \mathrm{wk}$, and $50 \mathrm{wk} / \mathrm{yr})$. Therefore, the occupancy-corrected quarterly limit is as follows:

Quarterly limit $=(50 \mathrm{mrem} / 4)(8760 \mathrm{~h} / 2000 \mathrm{~h})=55 \mathrm{mrem}$

The calculated 55-mrem quarterly limit was reduced to 40 mrem to allow for such factors as processing time, processing errors, the potential for individuals to be present more than $2000 \mathrm{~h}$ annually, and the potential for maximum exposure rates occurring during occupancy hours.

\subsection{Quality Assurance and Quality Control}

The Hanford External Dosimetry Project (HEDP) performed the measurements of the area TLDs. The HEDP laboratory is DOELAP accredited. Quality assurance and quality control programs are conducted in accordance with PNL-MA-859, Hanford External Dosimetry Project Quality Manual. 


\subsection{Results and Discussion}

A summary of the deep dose area monitoring TLD results for CY 2002 is provided in Table 3.1. Quarterly area monitoring TLD results are grouped into one of three dose ranges (i.e., $\leq 10 \mathrm{mrem} ;>10$ mrem but $<40 \mathrm{mrem} ; \geq 40 \mathrm{mrem})$. In six locations, deep dose results exceeded the quarterly investigation level of $40 \mathrm{mrem}$; however, none of these locations had potential personnel exposures of $50 \mathrm{mrem}$ after considering worker occupancy. The results support the conclusion that personnel dosimeters are not necessary for staff in the areas monitored by the area TLDs. A detailed discussion of these six area monitoring TLD locations is found in Section 3.1.

Table 3.1 - Summary of Area Monitoring TLD Results, CY 2002

\begin{tabular}{|l|c|}
\hline \multicolumn{1}{|c|}{ Parameter } & Quantity \\
\hline Number of area TLD locations & 117 \\
\hline Total number of area TLDs analyzed in CY 2002 & $457^{\mathrm{b}}$ \\
\hline Quarterly area TLD results by deep dose range: & \\
$\bullet \quad \leq 10$ mrem & 412 \\
$\bullet \quad>10$ mrem but $<40$ mrem & 20 \\
$\bullet \quad \geq 40$ mrem & 25 \\
\hline
\end{tabular}

a. This table provides data for routine area TLDs. No special area TLDs were located in the field during 2002.

b. The total number of area TLDs analyzed does not equal 468 (i.e., four times the number of area TLD locations) because locations were started and terminated at various times throughout the year and several area TLDs were lost.

The neutron dose readings from the Hanford Standard Dosimeters typically over-estimate neutron dose since they are calibrated to an unmoderated neutron source, and neutron fields in PNNL facilities are moderated by intervening shielding and building materials. To better quantify neutron doses, Hanford Combination Neutron Dosimeters were positioned at three locations starting in CY 2001 and continuing into CY 2002. Comparison of neutron results between the Hanford Standard Dosimeter and Hanford Combination Neutron Dosimeter are presented in Section 3.2, along with a discussion of six locations where the combined deep and neutron dose results for CY 2002 exceeded the quarterly investigation level of 40 mrem. 
Individual area monitoring TLD results for each quarter, as well as annual totals, are presented in Appendix C. The results in Appendix C are not corrected for worker occupancy. Assuming workers to be present $2000 \mathrm{~h} / \mathrm{yr}$, results should be multiplied by 0.23 to correct for worker occupancy.

\subsection{Area TLD Results (Deep Dose)}

Quarterly "deep dose" area monitoring TLD results for facilities located outside the 300 Area (622R, 747A, 747A Trl, 2400 Stevens, EMSL, ESB, LSL-II, PSL, RTL, and Sigma V) were $\leq 10$ mrem. The six locations with quarterly deep dose results $\geq 40$ mrem "investigation level" were located in the 300 Area. Four of the locations were in the 325 Building with one each in the 326 Building and the 3720 Building. Figure 3.1 shows the trend of annual deep dose results at the six locations since the PNNL program was initiated in 1993. Table 3.2 provides estimated annual doses to an individual at the locations for CY 2002 considering occupancy. Estimated doses were below the $50 \mathrm{mrem}$ annual dose, which requires personnel dosimetry for a declared pregnant worker, a minor, or a member of the public. Detailed reviews of each location are summarized below.

- $\quad$ TLD ID\# A3062 (325, Loc. 2) was located in Room 5 of the mezzanine of the 325 Building on the north wall about chest height. This location was initiated in 1993. The increase in dose since 1997 (see Figure 3.1) was due to increased waste handling and storage activities in the basement of the 325 Building. Waste is frequently stored along the south wall of the basement just below Room 5 . Routine surveys taken in the mezzanine annually showed that dose rates are less than the $50 \mu \mathrm{rem} / \mathrm{h}$ level requiring posting as a Radiological Buffer Area. Accounting for occupancy, an individual could have received approximately 44 mrem during CY 2002 (see Table 3.2).

- $\quad$ TLD ID\# A3175 (325, Loc. 5) and A3225 (325, Loc. 12) were located in the lunchroom of the east equipment room on the second floor of the 325 Building. This location was initiated in the second quarter of CY 1997. The annual deep dose result for CY 2002 had increased by approximately a factor of four over the doses in CY 1998 and CY 1999 (see Figure 3.1). The increase in deep dose results over the past three years was attributed to storage of additional radioactive material in Room 528 located below this area. To evaluate the significance of neutron dose readings reported from the Hanford Standard Dosimeter (A3175), a Hanford combination neutron dosimeter (A3225) was added to this location for a one-year period (third quarter 2001 through second quarter 2002). Table 3.3 compares the quarterly neutron dose readings from the Hanford Standard Dosimeter and the Hanford Combination Neutron Dosimeter. For this location, the Hanford Standard Dosimeter overestimated the neutron dose by a factor of approximately 7. The Hanford combination neutron dose (A3225) was discontinued the third quarter of CY2002 as enough information had been gathered on ratios of neutron dose from the standard dosimeter and the combination dosimeter. Accounting for occupancy, an individual could have received approximately 24 mrem during CY 2002 (see Table 3.2). 
- $\quad$ TLD ID\# A3176 (325, Loc. 6) was located in the copy room in the second floor office area of the 325 Building. This location was initiated in 1998. The annual deep dose result for CY 2002 increased by a factor of four over the results from the previous several years (see Figure 3.1). This increase was attributed to sample preparation work on high-activity filters located in room 700 . Much of the increased dose was from waste generated during this activity and stored in the room. The waste was removed during the fourth quarter of CY 2002 resulting in a significantly lower fourth quarter result. Accounting for occupancy, an individual could have received approximately 38 mrem during CY 2002 (see Table 3.2).

- TLD ID\# A3196 (325, Loc. 7) and A3226 (325, Loc. 11) were located on the wall between Room 115 and 116 on the first floor of the 325 Building. This location was started in the second quarter of CY 1999. The total deep dose for CY 2002 was 435 mrem about the same as previous years (see Figure 3.1). To evaluate the significance of neutron dose readings reported from the Hanford Standard Dosimeter (A3196) over the past several years, a Hanford Combination Neutron Dosimeter (A3226) was added to this location for a one-year period (third quarter 2001 through second quarter 2002). Table 3.3 compares the quarterly neutron dose readings from the Hanford Standard Dosimeter and the Hanford Combination Neutron Dosimeter. The Hanford Combination Neutron Dosimeter showed minimal neutron dose at this location. The Hanford combination neutron dose (A3225) was discontinued the third quarter of CY2002 as enough information had been gathered on ratios of neutron dose from the standard dosimeter and the combination dosimeter. Accounting for occupancy, an individual could have received approximately 25 mrem during CY 2002 (see Table 3.2).

- $\quad$ TLD ID\# A3178 (326, Loc. 7) was located on the east wall of Room $37 \mathrm{~B}$ in the 326 Building. This location was started during CY 1997. This was the first year with a quarterly result greater than the screening level. The fourth quarter result was $69 \mathrm{mrem}$. This dose was attributed to researchers sorting and disposing high-activity samples in Room 15/17A located directly below Room 37B. All staff in affected areas on the "B" floor were issued personal TLDs during the exposure period. Accounting for occupancy, an individual could have received approximately 36 mrem during CY 2002 (see Table 3.2).

- TLD ID\# A3048 (3720, Loc. 2) was located on the bulletin board in the lunchroom of the 3720 Building. This location was initiated in 1993. Total measured deep dose for CY 2002 was 172 mrem, which is similar to doses for the past four years (see Figure 3.1). As documented in past annual reports, the cause of the elevated readings in CY 1997 and CY 1998 was radioactive material stored in a shielded glovebox in a laboratory across the hall from the lunchroom (see Bivins and Stoetzel 1999). During April/May 1999, radioactive material stored in the shielded glovebox was moved to the 331 Building. Major contributors to dose at this location now are SX tank soil samples stored in Room 603 and 612 and the shielded sample storage area in Room 506. As documented in past annual reports, TLD \#A3048 is conservatively located on the wall next to the radioactive material. Accounting for occupancy, an individual could have received approximately 10 mrem during CY 2002 (see Table 3.2). 


\subsection{Routine Area TLD Results (Deep + Neutron Dose)}

Neutron dose results for the Hanford Standard Dosimeter are based on a calibration on a phantom to unmoderated neutrons from bare ${ }^{252} \mathrm{Cf}$. The neutrons typically reaching an area TLD location will be moderated by intervening shielding and building material; therefore, the dosimeter would be more appropriately calibrated in air to a ${ }^{252} \mathrm{Cf}$ source moderated by a $30-\mathrm{cm}$-diameter sphere of $\mathrm{D}_{2} \mathrm{O}$. This calibration showed that the neutron doses reported in Appendix $\mathrm{C}$ should be divided by a factor of 2.66 to obtain more accurate results. Field measurements made with a $\mathrm{BF}_{3}$ detector showed that the correction factor of 2.66 could also be conservatively used to correct neutron readings for a location in the 331 Building. To better define neutron doses from the Hanford Standard Dosimeter, Hanford Combination Neutron Dosimeters were placed at selected locations, which had elevated neutron readings in the past on the Hanford Standard Dosimeters. These locations were 1) 325, Loc. 5 (east equipment on the second floor), 2) 325, Loc. 7 (first floor hallway between Rooms 115 and 116), and 3) 326, Loc. 9 ( $\mathrm{Rm} 28 \mathrm{~B})$. Comparisons of neutron dose readings are found in Table 3.3. The results showed the Hanford Standard Dosimeter to over-respond by a factor of 1.1 - 9.2. The Hanford Standard Dosimeters in the 325 Building over-responded by an average of 7.0 compared to an average of only 1.5 in the 326 Building. The likely reason for this difference is that the source of the neutron exposure in the 326 Building is located closer to the area dosimeters with less intervening shielding compared to the neutron exposures in the 325 Building. Therefore, the 326 Building exposure configuration more closely aligns to the neutron calibration method for the Hanford Standard Dosimeter (i.e., calibration on a phantom to unmoderated neutron from bare ${ }^{252} \mathrm{Cf}$ ).

Four area TLD locations had quarterly readings exceeding the 40 mrem "investigation level" when totaling the deep dose and neutron dose reading. A discussion of the four area TLD locations is presented below:

- $\quad$ TLD ID\# A3063 (325, Loc. 3) was located on the second floor of the 325 Building outside Room 944. This location was initiated in CY 1998. Quarterly deep dose readings ranged from 17 to 28 mrem ( 84 mrem total) for CY 2002 which is similar to past years. Quarterly neutron doses ranged from 9 to $14 \mathrm{mrem}$ ( $36 \mathrm{mrem}$ total) which is similar to past years. Using the 2.66 correction factor, the annual neutron dose for CY 2002 is estimated to be 14 mrem. Accounting for occupancy, an individual could have received approximately 23 mrem during CY 2002 (see Table 3.2).

- $\quad$ TLD ID\# A3197 (325, Loc. 8) was located on the first floor of the 325 Building between Room 101 and 102. This location was initiated during the second quarter of CY 1999. Quarterly deep dose results for CY 2002 ranged from 20 to 28 mrem (93 mrem total for the year) which is similar to the quarterly results for previous years. Quarterly neutron doses ranged from 41 to 60 mrem (205 mrem total) for CY 2002, which is similar to the readings since the third quarter of CY 2000. Using the 2.66 correction factor, the annual neutron dose for CY 2002 is estimated to be $77 \mathrm{mrem}$. Doses are likely due to radioactive materials found in Room 22 of the basement below this hallway. Accounting for occupancy, an individual could have received approximately 10 mrem during CY 2002 (see Table 3.2). 
- TLD ID\# A3218 (326, Loc. 9) and A3222 (326, Loc. 10) were located on the second floor of the 326 Building in Room 28B under the window on the south wall. TLD A3218 (Hanford Standard Dosimeter) was initiated during the fourth quarter of CY 1999 and TLD A3222 (Hanford Combination Neutron Dosimeter) was initiated during the first quarter of CY 2002. The deep dose readings were insignificant $<10 \mathrm{mrem} /$ quarter which is similar to past years. Neutron results for this location are found in Table 3.3. Quarterly neutron dose results from Hanford Standard Dosimeter were from 1.1 to 1.3 greater than dose results from the Hanford Combination Neutron Dosimeter at this location. Neutron doses for all the quarters exceed the 40 mrem screening limit. The source of the neutron activity was neutron source storage in room 9A. When these sources are removed from their storage locations during projects, personnel are evacuated from the areas immediately above Room 9A. Accounting for occupancy, an individual could have received approximately $11 \mathrm{mrem}$ during CY 2002 (see Table 3.2).

- $\quad$ TLD ID\# A3095 (EMSL, Loc. 3) was located inside the caged area on the south wall of room 1648 (accelerator room). Personnel typically do not enter the caged area during accelerator operations but are not restricted from doing so. This location was initiated in CY 1997. Quarterly deep dose readings for CY 2002 ranged from 6-8 mrem, which is similar to past years. Quarterly neutron dose readings for CY 2001 ranged from 0-84 mrem (102 mrem total), which is somewhat higher than past years. The increased reading may be due to accelerator operations within the area when working at higher voltages. The Radiological Control organization has implemented several special studies to better understand the elevated neutron readings at this location to include the following: 1) placement of neutron TLDs and track etch dosimeters at EMSL, Loc. 3 and EMSL, Loc. 4, and 2) measurements with a low-level neutron counter during accelerator operations suspected of causing the elevated neutron readings. Results of the special studies were not yet available. Assuming no neutron correction factor, the annual neutron dose for CY 2002 is estimated to be $102 \mathrm{mrem}$. Accounting for occupancy, an individual could have received approximately 7 mrem during CY 2002 (see Table 3.2). 
Table 3.2 - Estimated Annual Dose to an Individual at Selected Locations, CY 2002

\begin{tabular}{|c|c|c|c|c|c|}
\hline Location & $\begin{array}{l}\text { Dosimeter } \\
\text { Number }\end{array}$ & $\begin{array}{l}\text { Annual } \\
\text { Area } \\
\text { TLD } \\
\text { Reading } \\
\text { (mrem) }\end{array}$ & $\begin{array}{l}\text { Estimated Dose to } \\
\text { Individual } \\
\text { Assuming Full- } \\
\text { Time Occupancy } \\
\text { (mrem) }^{a}\end{array}$ & $\begin{array}{l}\text { Occupancy } \\
\text { Factor }\end{array}$ & $\begin{array}{l}\text { Estimated Annual } \\
\text { Dose to Individual } \\
\text { After Occupancy } \\
\text { Corrections } \\
\text { (mrem) }\end{array}$ \\
\hline 325, Loc. 2 (Rm 5) & A3062 & 192 & 44 & 1 & 44 \\
\hline 325, Loc. $3(\mathrm{Rm} \mathrm{944)}$ & A3063 & $98^{\mathrm{b}}$ & 23 & 1 & 23 \\
\hline 325, Loc. 5 (east equip rm) & $\begin{array}{l}\text { A3175, } \\
\text { A3225 }\end{array}$ & $422^{c}$ & 97 & $1 / 4$ & 24 \\
\hline $\begin{array}{l}325, \text { Loc. } 6 \text { ( } 2^{\text {nd }} \text { floor, copy } \\
\text { room })\end{array}$ & A3176 & 655 & 151 & $1 / 4$ & 38 \\
\hline 325, Loc. 7 (Rm 115/116) & $\begin{array}{l}\text { A3196, } \\
\text { A3226 }\end{array}$ & $441^{d}$ & 101 & $1 / 4$ & 25 \\
\hline 325, Loc. 8 (Rm 101/102) & A3197 & $170^{\mathrm{e}}$ & 39 & $1 / 4$ & 10 \\
\hline 326. Loc. $7(\mathrm{Rm} 37 \mathrm{~B})$ & A3178 & 158 & 36 & 1 & 36 \\
\hline 326, Loc. 9 (Rm 28B) & $\begin{array}{l}\text { A3218, } \\
\text { A3222 }\end{array}$ & $195^{\mathrm{f}}$ & 45 & $1 / 4$ & 11 \\
\hline 3720, Loc. 2 (lunch room) & A3068 & 172 & 40 & $1 / 4$ & 10 \\
\hline EMSL, Loc. 3 (Accel Rm) & A3095 & $129^{\mathrm{g}}$ & 30 & $1 / 4$ & 7 \\
\hline
\end{tabular}

a. Full-time occupancy assumes 2000 hours/y; therefore, need to multiply value in previous column by 0.23 .

b. Dose was the sum of the deep dose reading for CY 2002 ( $84 \mathrm{mrem})$ and the neutron dose divided by $2.66(36 \mathrm{mrem} / 2.66=14 \mathrm{mrem})$

c. This dose represents the sum of the annual deep dose (394 mrem) and neutron dose ( $28 \mathrm{mrem})$. The neutron dose reading was taken from the Hanford Combination Neutron Dosimeter (A3225). The neutron dose for the first and second quarter was $14 \mathrm{mrem}$; therefore, the annual neutron dose was projected to be $\sim 28$ mrem.

d. This dose represents the sum of the annual deep dose (435 mrem) and neutron dose ( $\sim 6 \mathrm{mrem})$. The neutron dose reading was taken from the Hanford Combination Neutron Dosimeter (A3226). The neutron dose for the first and second quarter was $3 \mathrm{mrem}$; therefore, the annual neutron dose was projected to be $\sim 6$ mrem.

e. Dose was the sum of the deep dose reading for CY 2002 (93 mrem) and the neutron dose divided by $2.66(205 \mathrm{mrem} / 2.66=77 \mathrm{mrem})$.

f. This dose represents the sum of the annual deep dose (14 mrem) and neutron dose (181 mrem). The neutron dose reading was taken from the Hanford Combination Neutron Dosimeter (A3222).

g. Dose was the sum of the deep dose reading for CY $2002(27 \mathrm{mrem})$ and the neutron dose $(102 \mathrm{mrem})$. 
Table 3.3-Comparison of Neutron Doses between Hanford Standard Dosimeter and Hanford Combination Neutron Dosimeter, CY 2001 -2002

\begin{tabular}{|c|c|c|c|c|c|c|c|c|c|}
\hline \multirow[b]{3}{*}{ Quarter } & \multicolumn{9}{|c|}{ Neutron Dose (mrem) } \\
\hline & \multicolumn{3}{|c|}{ 325, Loc. 5 (East Equipment Rm) } & \multicolumn{3}{|c|}{ 325, Loc. 7 (Rm 115/116) } & \multicolumn{3}{|c|}{ 326, Loc. 9 (Rm 28B) } \\
\hline & $\begin{array}{c}\text { Std } \\
(\mathbf{A 3 1 7 5})\end{array}$ & $\begin{array}{l}\text { Combo } \\
\text { (A3225) }\end{array}$ & $\begin{array}{c}\text { Ratio } \\
\text { (Std/Combo) }\end{array}$ & $\begin{array}{c}\text { Std } \\
\text { (A3196) }\end{array}$ & $\begin{array}{l}\text { Combo } \\
\text { (A3226) }\end{array}$ & $\begin{array}{c}\text { Ratio } \\
\text { (Std/combo) }\end{array}$ & $\begin{array}{c}\text { Std } \\
(\mathbf{A 3 2 1 8})\end{array}$ & $\begin{array}{c}\text { Combo } \\
\text { (A3222) }\end{array}$ & $\begin{array}{c}\text { Ratio } \\
\text { (Std/combo) }\end{array}$ \\
\hline 2001-1 & - & - & - & - & - & - & 82 & 23 & 3.6 \\
\hline $2001-2$ & - & - & - & - & - & - & 34 & 9 & 3.8 \\
\hline 2001-3 & 80 & 14 & 5.7 & 24 & 0 & - & 68 & 44 & 1.6 \\
\hline $2001-4$ & 75 & 11 & 6.8 & 0 & 0 & - & 61 & 51 & 1.2 \\
\hline $2002-1$ & 64 & 8 & 8.0 & 20 & 3 & 6.7 & 56 & 50 & 1.1 \\
\hline $2002-2$ & 55 & 6 & 9.2 & 20 & 0 & - & 49 & 40 & 1.2 \\
\hline $2002-3$ & - & - & - & - & - & - & 56 & 42 & 1.3 \\
\hline $2002-4$ & - & - & - & - & - & - & 53 & 49 & 1.1 \\
\hline Total & 274 & 39 & 7.0 & 64 & 3 & 21 & 459 & 308 & 1.5 \\
\hline
\end{tabular}




\section{Figure 3.1 CY 2002 Deep Dose Trend Data}

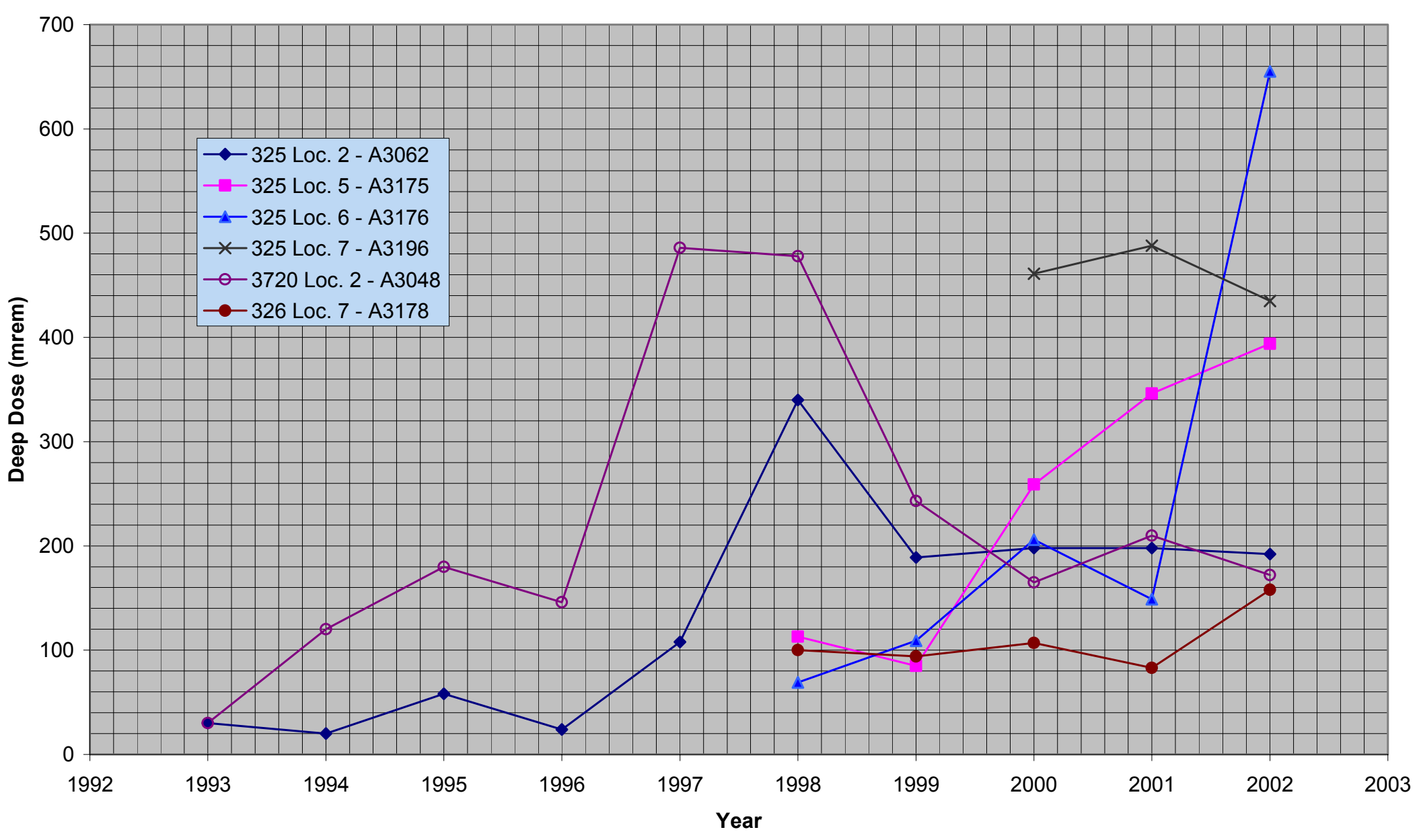




\subsection{Conclusions}

The area monitoring TLD program for CY 2002 was a useful tool in determining exposure trends in work areas located outside radiological areas. All routine area monitoring TLD results were less than 50 mrem annually after correcting for worker occupancy. The results support the conclusion that personnel dosimeters are not required for staff in these monitored areas. 


\subsection{References}

Bivins SR, and GA Stoetzel. 1996a. Area Monitoring Dosimeter Program for the Pacific Northwest National Laboratory: Results for CY 1993 and CY 1994. PNNL-11088, Pacific Northwest National Laboratory, Richland, Washington.

Bivins SR, and GA Stoetzel. 1996b. Area Monitoring Dosimeter Program for the Pacific Northwest National Laboratory: Results for CY 1995. PNNL-11185, Pacific Northwest National Laboratory, Richland, Washington.

Bivins SR, and GA Stoetzel. 1997. Area Monitoring Dosimeter Program for the Pacific Northwest National Laboratory: Results for CY 1996. PNNL-11594, Pacific Northwest National Laboratory, Richland, Washington.

Bivins SR, and GA Stoetzel. 1998. Area Monitoring Dosimeter Program for the Pacific Northwest National Laboratory: Results for CY 1997. PNNL-11924, Pacific Northwest National Laboratory, Richland, Washington.

Bivins SR, and GA Stoetzel. 1999. Area Monitoring Dosimeter Program for the Pacific Northwest National Laboratory: Results for CY 1998. PNNL-12215, Pacific Northwest National Laboratory, Richland, Washington.

Bivins SR, and GA Stoetzel. 2000. Area Monitoring Dosimeter Program for the Pacific Northwest National Laboratory: Results for CY 1999. PNNL-13322, Pacific Northwest National Laboratory, Richland, Washington.

Bivins SR, and GA Stoetzel. 2001. Area Monitoring Dosimeter Program for the Pacific Northwest National Laboratory: Results for CY 2000. PNNL-13604, Pacific Northwest National Laboratory, Richland, Washington.

Bivins SR, and GA Stoetzel. 2002. Area Monitoring Dosimeter Program for the Pacific Northwest National Laboratory: Results for CY 2001. PNNL-13937, Pacific Northwest National Laboratory, Richland, Washington.

National Council on Radiation Protection and Measurements (NCRP). 1976. Structural Shielding Design and Evaluation for Medical Use of X Rays and Gamma Rays of Energies Up to $10 \mathrm{MeV}$. NCRP Report No. 49, NCRP, Washington, DC 20014.

PNL-MA-266, PNL Radiological Control Implementing Procedures.

PNL-MA-842, Hanford External Dosimetry Project Technical Basis Manual.

PNL-MA-859, Hanford External Dosimetry Project Quality Manual. 
PNNL Radiological Control Program Description, November 1999.

U.S. Department of Energy (DOE). 1994. Radiological Control Manual. DOE/EH-0256T, Rev. 1, Washington, D.C.

U.S. Department of Energy (DOE). 1999. DOE Standard-Radiological Control. DOE-STD-1098-99. July 1999. Washington, D.C. 


\section{Appendix A}

\section{Area TLD - Processing, Calibration, and Dose Assessment}

\section{A.1 Processing}

Harshaw 8800 series automated reader systems were used to process the area thermoluminescent dosimeters (TLDs) (i.e., Hanford Standard Dosimeter and Hanford Combination Neutron Dosimeter). Automated processing steps included the following:

- Pre-issue reader annealings: each dosimeter card is processed through the automated reader systems to remove any remaining residual signal from past occupational exposure or environmental background radiation. Each dosimeter card is annealed at $80^{\circ} \mathrm{C}$ for $16 \mathrm{~h}$ before being issued.

- Reader processing: the reader heats all chips simultaneously at a rate of $25^{\circ} \mathrm{C} / \mathrm{s}$ until a maximum temperature of $300^{\circ} \mathrm{C}$ is obtained.

- Glow-curve recording: the glow curve of all dosimeters is recorded and stored for a period of approximately 2 years.

\section{A.2 Calibration}

Area TLDs were calibrated using sources traceable to the National Institute of Standards and Technology (NIST). The primary calibration was the deep dose from an on-phantom ${ }^{137}$ Cs exposure.

\section{A.3 Dose Assessment}

The contribution to the area TLD from naturally occurring environmental radiation was determined using the following equation:

$$
\mathrm{E}_{\mathrm{i}}=\mathrm{G}_{\mathrm{i}}(\mathrm{FD}-\mathrm{BD})
$$

where $\mathrm{E}_{\mathrm{i}} \quad=$ estimated environmental background for chip i $\left({ }^{60} \mathrm{Co} \mathrm{mR}\right.$-equivalent $)$

$\mathrm{G}_{\mathrm{i}} \quad=$ background growth rate $(\mathrm{mR} / \mathrm{d})$

FD = field cycle days (days between previous and current processing date)

$\mathrm{BD}=$ blank days (mean days between previous and current processing for blank cards). 
The adjusted chip readings are calculated using the following equation:

$$
D_{i}=\frac{X_{i} B_{i} E_{i}}{\left(R R F_{i}^{*} F_{i}\right)}
$$

where $\mathrm{D}_{\mathrm{i}} \quad=$ adjusted chip reading for chip $\mathrm{i}\left({ }^{137} \mathrm{C}\right.$ rem-equivalent $)$

$\mathrm{X}_{\mathrm{i}} \quad=$ calibrated chip reading for chip i $\left({ }^{60} \mathrm{Co} \mathrm{mR}\right.$-equivalent $)$

$\mathrm{Bi}=$ mean calibrated chip i reading from blank cards $\left({ }^{60} \mathrm{Co} \mathrm{mR}\right.$-equivalent $)$

$\mathrm{E}_{\mathrm{i}} \quad=$ estimated environmental background for chip i $\left({ }^{60} \mathrm{Co} \mathrm{mR}\right.$-equivalent $)$

$\mathrm{RRF}_{\mathrm{i}}={ }^{137} \mathrm{Cs}$ relative response factor (RRF) for chip i (mR/rem)

$\mathrm{F}_{\mathrm{i}} \quad=$ fade factor for chip $\mathrm{i}$.

Area TLD readings were provided for shallow dose, deep dose, neutron dose, and eye dose. Only deep dose and neutron results are included for discussion in this report.

\section{A.4 Dose Algorithm}

Dose algorithms for the Hanford Standard Dosimeter and Hanford Combination Neutron Dosimeter are found in Section 8 of PNL-MA-568.

\section{A.5 Quality Control Program}

Quality assurance and quality control programs are conducted in accordance with Section 5 of PNLMA-859, Hanford External Dosimetry Project Quality Manual. 


\section{Appendix B}

\section{Locations of Area Monitoring TLDs}

\begin{tabular}{|c|c|c|c|}
\hline BLDG & TLD ID \# & Location ID \# & Description of Location \\
\hline & & Routine TLDs & \\
\hline $305-\mathrm{B}$ & A3001 & LOC. 1 & South wall of Room 2 near vending machine \\
\hline $306-\mathrm{W}$ & A3034 & LOC. 1 & Main entrance on first bulletin board \\
\hline $306-\mathrm{W}$ & A3035 & LOC. 2 & Second floor lunchroom \\
\hline $306-\mathrm{W}$ & A3036 & LOC. 3 & First floor - Room 131 \\
\hline 318 & A3040 & LOC. 2 & Main corridor of second floor across from Room 202 \\
\hline 318 & A3192 & LOC. 4 & First floor - main corridor outside Room 121 \\
\hline 318 & A3193 & LOC. 5 & Bulletin board across from Room 1128 (facing north) \\
\hline 318 & A3194 & LOC. 6 & Room 169 (copy room) - north wall \\
\hline 318 & A3022 & TRL. 4 & Bulletin board on the north wall (main entrance) \\
\hline 320 & A 3042 & LOC. 1 & Lobby \\
\hline 320 & A3043 & LOC. 2 & Basement on bulletin board outside of Room 5 on east wall \\
\hline 323 & A3195 & LOC. 1 & Lunchroom on south wall facing hot cell area \\
\hline 325 & A3061 & LOC. 1 & Main lobby near north door \\
\hline 325 & A3062 & LOC. 2 & Mezzanine, Room 5, north wall (chest height) \\
\hline 325 & A3063 & LOC. 3 & Second floor - outside of Room 944 \\
\hline 325 & A3174 & LOC. 4 & Lunchroom (second floor) \\
\hline 325 & A3175 & LOC. 5 & East equipment room (second floor, lunch area) \\
\hline 325 & A3176 & LOC. 6 & Copy Room (second floor) \\
\hline 325 & A3196 & LOC. 7 & First floor hallway between Rooms 115 and 116 \\
\hline 325 & A3197 & LOC. 8 & First floor hallway between Rooms 101 and 102 \\
\hline 325 & A3198 & LOC. 9 & Mezzanine, Room 76 \\
\hline 325 & A3199 & LOC. 10 & Mezzanine, Room 17 \\
\hline 325 & A 3226 & LOC. 11 & $\begin{array}{l}\text { First floor hallway between Rooms } 115 \text { and } 116 \text { ) - Hanford } \\
\text { Combination Neutron Dosimeter }\end{array}$ \\
\hline 325 & A 3225 & LOC. 12 & $\begin{array}{l}\text { East equipment room (second floor, lunch area) - Hanford } \\
\text { Combination Neutron Dosimeter }\end{array}$ \\
\hline 326 & A3064 & LOC. 1 & First floor - bulletin board in copy area (Room 15) \\
\hline 326 & A3065 & LOC. 2 & First floor - in front of exit door to basement \\
\hline 326 & A3066 & LOC. 3 & First floor - in corridor across from Room 48-B \\
\hline 326 & A3067 & LOC. 4 & Second floor - lunchroom bulletin board \\
\hline 326 & A3068 & LOC. 5 & Second floor - corridor near Room 40-C \\
\hline
\end{tabular}




\begin{tabular}{|c|c|c|c|}
\hline BLDG & TLD ID \# & Location ID \# & Description of Location \\
\hline 326 & A3157 & LOC. 6 & Basement - Room 14A bulletin board \\
\hline 326 & A3178 & LOC. 7 & Room 37B (second floor, east wall) \\
\hline 326 & A3200 & LOC. 8 & Second floor on bulletin board opposite Room 30-C \\
\hline 326 & A3218 & LOC. 9 & Second floor, Room 28B, under window on south wall \\
\hline 326 & A3222 & LOC. 10 & $\begin{array}{l}\text { Second floor, Room 28B, under window on south wall (Hanford } \\
\text { Combination Neutron Dosimeter) }\end{array}$ \\
\hline 329 & A3071 & LOC. 1 & Lunchroom \\
\hline 329 & A3072 & LOC. 2 & Room 115 - east wall \\
\hline 329 & A3074 & LOC. 4 & North-south hallway (Room 2) \\
\hline 329 & A3075 & LOC. 5 & North-south hallway (Room 6-C) \\
\hline 329 & A3173 & LOC. 8 & Room 129 (above sink) \\
\hline 331 & A3044 & LOC. 1 & First floor - mail room \\
\hline 331 & A3045 & LOC. 2 & Second floor hallway on bulletin board outside of Room 22 \\
\hline 331 & A3046 & LOC. 3 & Third floor - Room 45 \\
\hline 331 & A3201 & LOC. 4 & First floor on bulletin board (east wall of Room 166B) \\
\hline 331 & A3202 & LOC. 5 & First floor on bulletin board (east wall of Room 113A) \\
\hline 331 & A3203 & LOC. 6 & First floor on bulletin board (northeast wall of Room 164) \\
\hline 331 & A3204 & LOC. 7 & First floor, Room 164 on northeast wall \\
\hline 331 & A3205 & LOC. 8 & First floor - outside of Room 110 \\
\hline 331 & A3206 & LOC. 9 & Second floor in corridor opposite of Room 30 \\
\hline $331 \mathrm{C}$ & A3207 & LOC. 1 & North wall by entrance door \\
\hline $331 \mathrm{D}$ & A3208 & LOC. 1 & North wall by entrance door \\
\hline $331 \mathrm{H}$ & A3209 & LOC. 1 & Bulletin board by airlock area \\
\hline $336-1$ & A3073 & LOC. 1 & Bulletin board in Room 5 on east wall at entrance to Room 6 \\
\hline 337 & A3080 & LOC. 1 & First floor south - west wall of Room 1114 \\
\hline 337 & A3081 & LOC. 2 & First floor north - east wall of Room 1225 \\
\hline 337 & A3082 & LOC. 3 & Second floor south - west wall of Room 2112 \\
\hline 337 & A3083 & LOC. 4 & Second floor north - north wall of Room 2213 \\
\hline 337 & A3084 & LOC. 5 & Third floor south - Room 3124 \\
\hline 337 & A3085 & LOC. 6 & Third floor north - Mt. Rainier Room \\
\hline 338 & A3177 & LOC. 1 & Conference Room/lunchroom (Room 24) - west wall \\
\hline 350 & A3004 & LOC. 1 & Bulletin board in Room 137 \\
\hline 350 & A3005 & LOC. 2 & Bulletin board between Rooms 158 and 175 \\
\hline $622-\mathrm{R}$ & A3086 & LOC. 1 & Room 110 by red phone \\
\hline $622-\mathrm{R}$ & A3087 & LOC. 2 & Exit sign in front of men's room \\
\hline $747-\mathrm{A}$ & A3088 & LOC. 1 & Bulletin board on west wall by scale \\
\hline $747-\mathrm{A}$ & A3089 & TRL.1, LOC. 1 & Bulletin board by south door \\
\hline 2400 & A3113 & LOC. 1 & Secretary's desk located in main entrance \\
\hline 2400 & A3114 & LOC. 2 & Bulletin board in entry way to Room 1414 \\
\hline
\end{tabular}




\begin{tabular}{|c|c|c|c|}
\hline BLDG & TLD ID \# & Location ID \# & Description of Location \\
\hline 2400 & $\mathrm{~A} 3115$ & LOC. 3 & High-bay bulletin board in entry to Lab 1445 \\
\hline 2400 & A3116 & LOC. 4 & Second floor on bulletin board outside of Room 2428 \\
\hline 3718-A & A3006 & LOC. 1 & Bulletin board outside of main office \\
\hline 3720 & A3047 & LOC. 1 & North and south corridor across from Room 221 \\
\hline 3720 & A3048 & LOC. 2 & Bulletin board in lunchroom (Room 401), north wall \\
\hline 3730 & A3049 & LOC. 1 & Desk area near computers \\
\hline 3760 & A3009 & LOC. 1 & Lobby \\
\hline 3760 & A3010 & LOC. 2 & Second floor Room 215 (SE cubicle) \\
\hline APEL & A3217 & LOC. 1 & Room 102 on north wall by radiation generating device \\
\hline APEL & A3228 & LOC. 2 & Room 80 \\
\hline BRSW & A3227 & LOC. 1 & Room 1 (receiving area above desk on fence) \\
\hline EMSL & A3093 & LOC. 1 & Accelerator Room (north wall) \\
\hline EMSL & A3094 & LOC. 2 & Accelerator Room (east wall) \\
\hline EMSL & A3095 & LOC. 3 & Accelerator Room (south wall enclosure) \\
\hline EMSL & A3096 & LOC. 4 & Accelerator Room (south wall) \\
\hline EMSL & A3097 & LOC. 5 & Accelerator Room (west wall) \\
\hline EMSL & A3098 & LOC. 6 & Accelerator Room (control console) \\
\hline EMSL & A3211 & LOC. 7 & Room 1422 on south wall by phone \\
\hline EMSL & A3212 & LOC. 8 & Room 1330 on south wall \\
\hline EMSL & A3213 & LOC. 9 & Room 1330 on east wall under cabinet \\
\hline EMSL & A3214 & LOC. 10 & Room 1330 on southwest wall \\
\hline EMSL & A3219 & LOC. 11 & Room 1330, x-ray machine \\
\hline EMSL & A3220 & LOC. 12 & Room 1422 , x-ray machine \\
\hline EMSL & A3223 & LOC. 13 & Room 1330 on north wall \\
\hline EMSL & A3224 & LOC. 14 & Room 1330 on northeast wall \\
\hline ESB & A3092 & LOC. 2 & Entry way to Room 31 \\
\hline LSL-II & A3167 & LOC. 1 & Lunchroom \\
\hline LSL-II & A3168 & LOC. 2 & Corridor outside of Lab 1404 \\
\hline LSL-II & A3169 & LOC. 3 & Lab 1508 \\
\hline LSL-II & A3170 & LOC. 4 & Lab 1419 \\
\hline LSL-II & A3171 & LOC. 5 & Office 1224 \\
\hline LSL-II & A3172 & LOC. 6 & Lab 1336 \\
\hline PSL & A3099 & LOC. 1 & Lab 1611 \\
\hline PSL & A3100 & LOC. 2 & Bulletin board in Lab 1504 \\
\hline PSL & A3101 & LOC. 3 & East entrance on secretary's desk \\
\hline PSL & A3102 & LOC. 4 & Bulletin board in Lab 1304 \\
\hline PSL & A3103 & LOC. 5 & Corridor outside of Lab 315 \\
\hline PSL & A3210 & LOC. 6 & Room 1308 on west wall under cabinet \\
\hline RTL & A3105 & LOC. 1 & Lab 428 \\
\hline
\end{tabular}




\begin{tabular}{|c|c|c|l||}
\hline BLDG & TLD ID $\#$ & Location ID $\#$ & \multicolumn{1}{|c||}{ Description of Location } \\
\hline RTL & A3106 & LOC. 2 & Lab 328 \\
\hline RTL & A3107 & LOC. 3 & Lab 218 \\
\hline RTL & A3108 & LOC. 4 & Outside Room 127 Secretary office \\
\hline RTL & A3109 & LOC. 5 & Canteen above fire extinguisher \\
\hline RTL & A3110 & LOC. 6 & Bulletin board in Room 21-A \\
\hline Sigma V & A3186 & LOC. 1 & Room 1519 - west wall \\
\hline Sigma V & A3187 & LOC. 2 & Room 1519 - south wall \\
\hline Sigma V & A3188 & LOC. 3 & Room 1519 - north wall \\
\hline Sigma V & A3189 & LOC. 4 & Room 1227 - north wall \\
\hline Sigma V & A3190 & LOC. 5 & Room 1523 - west wall \\
\hline Sigma V & A3191 & LOC. 6 & Room 1519 - ceiling \\
\hline
\end{tabular}




\section{Appendix C}

Area Monitoring TLD Results for CY $2002^{(\mathrm{a})}$

\begin{tabular}{|c|c|c|c|c|c|c|}
\hline TLD Location & TLD ID\# & Deep Dose (mrem) & Deep Dose (mrem) & Deep Dose (mrem) & Deep Dose (mrem) & Deep Dose (mrem) \\
\hline & & 1st Quarter & 2nd Quarter & 3rd Quarter & 4th Quarter & Annual \\
\hline 305B LOC. 1 & A3001 & 0 & 1 & 1 & 1 & 3 \\
\hline 306W LOC. 1 & A3034 & 2 & 2 & 3 & 1 & 8 \\
\hline 306W LOC. 2 & A3035 & 3 & 3 & 3 & 2 & 11 \\
\hline 306W LOC. 3 & A3036 & 4 & 7 & 8 & 8 & 27 \\
\hline 318 LOC. 2 & A3040 & 3 & 3 & 2 & 2 & 10 \\
\hline 318 LOC. 4 & A3192 & 0 & 0 & 0 & 1 & 1 \\
\hline 318 LOC. 5 & A3193 & 0 & 0 & 1 & 0 & 1 \\
\hline 318 LOC. 6 & A3194 & 2 & 1 & 1 & 1 & 5 \\
\hline 318 TRL. 4 & A3022 & 0 & 0 & 0 & 0 & 0 \\
\hline 320 LOC. 1 & A3042 & 0 & 1 & 0 & 2 & 3 \\
\hline 320 LOC. 2 & A3043 & 5 & 5 & 4 & 5 & 19 \\
\hline 323 LOC. 1 & A3195 & 3 & 2 & 4 & 3 & 12 \\
\hline 325 LOC. 1 & A3061 & 0 & 0 & 1 & 0 & 1 \\
\hline 325 LOC. 2 & A3062 & 42 & 49 & 48 & 53 & 192 \\
\hline 325 LOC. 3 & A3063 & $28(13)^{\mathrm{e}}$ & $20(14)^{\mathrm{e}}$ & $17(9)^{\mathrm{e}}$ & 19 & $84(36)^{\mathrm{e}}$ \\
\hline 325 LOC. 4 & A3174 & 1 & 2 & 3 & 2 & 8 \\
\hline 325 LOC. 5 & A3175 & $76(64)^{e}$ & $115(55)^{\mathrm{e}}$ & $75(25)^{\mathrm{e}}$ & 128 & $394(144)^{\mathrm{e}}$ \\
\hline 325 LOC. 6 & A3176 & 68 & 180 & 251 & 156 & 655 \\
\hline 325 LOC. 7 & A3196 & $102(20)^{\mathrm{e}}$ & $108(20)^{\mathrm{e}}$ & $110(25)^{\mathrm{e}}$ & 115 & $435(65)^{\mathrm{e}}$ \\
\hline 325 LOC. 8 & A3197 & $22(57)^{\mathrm{e}}$ & $20(60)^{\mathrm{e}}$ & $28(41)^{\mathrm{e}}$ & $23(47)^{\mathrm{e}}$ & $93(205)^{\mathrm{e}}$ \\
\hline
\end{tabular}


Area Monitoring TLD Results for CY 2002 ${ }^{\text {(a) }}$ (continued)

\begin{tabular}{|c|c|c|c|c|c|c|}
\hline TLD Location & TLD ID\# & Deep Dose (mrem) & Deep Dose (mrem) & Deep Dose (mrem) & Deep Dose (mrem) & Deep Dose (mrem) \\
\hline & & 1st Quarter & 2nd Quarter & 3rd Quarter & 4th Quarter & Annual \\
\hline 325 LOC. 9 & A3198 & 17 & 16 & 17 & 11 & 61 \\
\hline 325 LOC. 10 & A3199 & 9 & 11 & 8 & 11 & 39 \\
\hline 325 LOC. 11 & A3226 (Combo) & $165(3)^{\mathrm{f}}$ & $132(0)^{\mathrm{f}}$ & (d) & (d) & $297(3)^{\mathrm{f}}$ \\
\hline 325 LOC. 12 & A3225 (Combo) & $72(8)^{\mathrm{f}}$ & $105(6)^{\mathrm{f}}$ & (d) & (d) & $177(14)^{\mathrm{f}}$ \\
\hline 326 LOC. 1 & A3064 & 1 & 0 & 0 & 1 & 2 \\
\hline 326 LOC. 2 & A3065 & $0(23)^{\mathrm{e}}$ & $1(18)^{\mathrm{e}}$ & $0(19)^{\mathrm{e}}$ & $1(20)^{\mathrm{e}}$ & $2(80)^{\mathrm{e}}$ \\
\hline 326 LOC. 3 & A3066 & 0 & 0 & 1 & 0 & 2 \\
\hline 326 LOC. 4 & A3067 & 0 & 0 & 0 & 0 & 0 \\
\hline 326 LOC. 5 & A3068 & 1 & 1 & 1 & 1 & 4 \\
\hline 326 LOC. 6 & A3157 & 1 & 1 & 6 & (b) & 8 \\
\hline 326 LOC. 7 & A3178 & 24 & 26 & 39 & 69 & 158 \\
\hline 326 LOC. 8 & A3200 & 1 & 0 & 0 & 0 & 1 \\
\hline 326 LOC. 9 & A3218 & $3(56)^{\mathrm{e}}$ & $5(49)^{\mathrm{e}}$ & $3(56)^{\mathrm{e}}$ & $3(53)^{\mathrm{e}}$ & $14(214)^{\mathrm{e}}$ \\
\hline 326 LOC. 10 & A3222 (Combo) & $9(50)^{\mathrm{f}}$ & $7(40)^{f}$ & $8(42)^{f}$ & $9(49)^{\mathrm{f}}$ & $33(181)^{f}$ \\
\hline 329 LOC. 1 & A3071 & 0 & 0 & 0 & 0 & 0 \\
\hline 329 LOC. 2 & A3072 & 0 & 0 & 0 & 0 & 0 \\
\hline 329 LOC. 4 & A3074 & 0 & 1 & 0 & 1 & 2 \\
\hline 329 LOC. 5 & A3075 & $0(11)^{\mathrm{e}}$ & $0(15)^{\mathrm{e}}$ & $0(8)^{\mathrm{e}}$ & $1(13)^{\mathrm{e}}$ & $1(47)^{\mathrm{e}}$ \\
\hline 329 LOC. 8 & A3173 & 11 & 3 & 17 & 12 & 43 \\
\hline 331 LOC. 1 & A3044 & 1 & 1 & 1 & 1 & 4 \\
\hline 331 LOC. 2 & A3045 & 1 & 1 & 1 & 2 & 5 \\
\hline 331 LOC. 3 & A3046 & 3 & 2 & 3 & (b) & 8 \\
\hline 331 LOC. 4 & A3201 & 1 & 0 & 1 & 1 & 3 \\
\hline 331 LOC. 5 & A3202 & $2(15)^{\mathrm{e}}$ & $1(14)^{\mathrm{e}}$ & 2 & 2 & $7(29)^{\mathrm{e}}$ \\
\hline 331 LOC. 6 & A3203 & $0(17)^{\mathrm{e}}$ & $1(19)^{\mathrm{e}}$ & 1 & 1 & $3(36)^{\mathrm{e}}$ \\
\hline 331 LOC. 7 & A3204 & 8 & 9 & 8 & 7 & 32 \\
\hline
\end{tabular}


Area Monitoring TLD Results for CY 2002 ${ }^{\text {(a) }}$ (continued)

\begin{tabular}{|c|c|c|c|c|c|c|}
\hline TLD Location & TLD ID\# & Deep Dose (mrem) & Deep Dose (mrem) & Deep Dose (mrem) & Deep Dose (mrem) & Deep Dose (mrem) \\
\hline & & 1st Quarter & 2nd Quarter & 3rd Quarter & 4th Quarter & Annual \\
\hline 331 LOC. 8 & A3205 & $1(26)^{\mathrm{e}}$ & $2(30)^{\mathrm{e}}$ & 1 & 1 & $5(56)^{\mathrm{e}}$ \\
\hline 331 LOC. 9 & A3206 & 1 & 2 & 2 & 1 & 6 \\
\hline 331C, LOC. 1 & A3207 & 1 & 0 & 0 & 1 & 2 \\
\hline 331D, LOC. 1 & A3208 & 0 & 0 & 0 & 1 & 1 \\
\hline 331H, LOC. 1 & A3209 & 2 & 3 & 2 & 4 & 11 \\
\hline 336-1, LOC. 1 & A3073 & 3 & 3 & 3 & 3 & 12 \\
\hline 337 LOC. 1 & A3080 & 1 & 1 & 1 & 2 & 5 \\
\hline 337 LOC. 2 & A3081 & 2 & 2 & 3 & 4 & 11 \\
\hline 337 LOC. 3 & A3082 & 4 & 6 & 6 & 5 & 21 \\
\hline 337 LOC. 4 & A3083 & 1 & 3 & 4 & 4 & 12 \\
\hline 337 LOC. 5 & A3084 & 3 & 3 & 3 & 3 & 12 \\
\hline 337 LOC. 6 & A3085 & 4 & 4 & 4 & 3 & 15 \\
\hline 338 LOC. 1 & A3177 & 0 & 0 & 0 & 0 & 0 \\
\hline 350 LOC. 1 & A3004 & 0 & 0 & 0 & 1 & 1 \\
\hline 350 LOC. 2 & A3005 & 0 & 0 & 0 & 0 & 0 \\
\hline 622R, LOC. 1 & A3086 & 4 & 4 & 4 & 4 & 16 \\
\hline 622R, LOC. 2 & A3087 & 3 & 2 & 2 & 2 & 9 \\
\hline 747A, LOC. 1 & A3088 & 0 & 1 & 0 & 0 & 1 \\
\hline 747A, Trl LOC. 1 & A3089 & 0 & 0 & 0 & 0 & 0 \\
\hline 2400 LOC. 1 & A3113 & 0 & 0 & 0 & 0 & 0 \\
\hline 2400 LOC. 2 & A3114 & 0 & 0 & 0 & 0 & 0 \\
\hline 2400 LOC. 3 & A3115 & 0 & 0 & 0 & 0 & 0 \\
\hline 2400 LOC. 4 & A3116 & 0 & 0 & 0 & 0 & 0 \\
\hline 3718A, LOC. 1 & A3006 & 0 & 0 & (d) & (d) & 0 \\
\hline
\end{tabular}


Area Monitoring TLD Results for CY 2002 ${ }^{\text {(a) }}$ (continued)

\begin{tabular}{|c|c|c|c|c|c|c|}
\hline TLD Location & TLD ID\# & Deep Dose (mrem) & Deep Dose (mrem) & Deep Dose (mrem) & Deep Dose (mrem) & Deep Dose (mrem) \\
\hline & & 1st Quarter & 2nd Quarter & 3rd Quarter & 4th Quarter & Annual \\
\hline 3720 LOC. 1 & A3047 & 3 & 4 & 3 & 3 & 13 \\
\hline 3720 LOC. 2 & A3048 & 45 & 43 & 44 & 40 & 172 \\
\hline 3730 LOC. 1 & A3049 & 2 & 3 & 7 & 2 & 14 \\
\hline 3760 LOC. 1 & A3009 & 2 & 2 & 2 & 2 & 8 \\
\hline 3760 LOC. 2 & A3010 & 0 & 0 & 0 & 0 & 0 \\
\hline APEL LOC. 1 & A3217 & 3 & 0 & 0 & 0 & 3 \\
\hline APEL LOC. 2 & A3228 & (c) & (c) & 1 & 1 & 2 \\
\hline BRSW LOC. 1 & A3227 & (c) & 1 & 3 & 1 & 5 \\
\hline EMSL LOC. 1 & A3093 & 5 & 7 & $4(18)^{\mathrm{e}}$ & 6 & $22(18)^{\mathrm{e}}$ \\
\hline EMSL LOC. 2 & A3094 & 8 & 7 & $6(27)^{\mathrm{e}}$ & 9 & $30(27)^{\mathrm{e}}$ \\
\hline EMSL LOC. 3 & A3095 & 7 & 6 & $6(84)^{\mathrm{e}}$ & $8(18)^{\mathrm{e}}$ & $27(102)^{\mathrm{e}}$ \\
\hline EMSL LOC. 4 & A3096 & 6 & 6 & 4 & 5 & 21 \\
\hline EMSL LOC. 5 & A3097 & 4 & 5 & 4 & 5 & 18 \\
\hline EMSL LOC. 6 & A3098 & 2 & 3 & $2(21)^{\mathrm{e}}$ & 3 & $10(21)^{\mathrm{e}}$ \\
\hline EMSL LOC. 7 & A3211 & 0 & 0 & 0 & 1 & 1 \\
\hline EMSL LOC. 8 & A3212 & 0 & 0 & 0 & 3 & 3 \\
\hline EMSL LOC. 9 & A3213 & 0 & 0 & 0 & 0 & 0 \\
\hline EMSL LOC. 10 & A3214 & 0 & 0 & 0 & 0 & 0 \\
\hline EMSL LOC. 11 & A3219 & 0 & 0 & 0 & 0 & 0 \\
\hline EMSL LOC. 12 & A3220 & 0 & 0 & 0 & 0 & 0 \\
\hline EMSL LOC. 13 & A3223 & 0 & 0 & 0 & 0 & 0 \\
\hline EMSL LOC. 14 & A3224 & 0 & 0 & 0 & 0 & 0 \\
\hline ESB LOC. 2 & A3092 & 0 & 0 & 0 & 0 & 0 \\
\hline LSL-II LOC. 1 & A3167 & 4 & 4 & 4 & 5 & 19 \\
\hline LSL-II LOC. 2 & A3168 & 1 & 1 & 2 & 1 & 5 \\
\hline LSL-II LOC. 3 & A3169 & 4 & 3 & 2 & 3 & 12 \\
\hline
\end{tabular}


Area Monitoring TLD Results for CY 2001 ${ }^{\text {(a) }}$ (continued)

\begin{tabular}{|c|c|c|c|c|c|c|}
\hline TLD Location & TLD ID\# & Deep Dose (mrem) & Deep Dose (mrem) & Deep Dose (mrem) & Deep Dose (mrem) & Deep Dose (mrem) \\
\hline & & 1st Quarter & 2nd Quarter & 3rd Quarter & 4th Quarter & Annual \\
\hline LSL-II LOC. 4 & A3170 & 2 & 3 & 1 & 3 & 9 \\
\hline LSL-II LOC. 5 & A3171 & 4 & 5 & 4 & 5 & 18 \\
\hline LSL-II LOC. 6 & A3172 & 3 & 3 & 3 & 5 & 14 \\
\hline PSL LOC. 1 & A3099 & 1 & 1 & 0 & 1 & 3 \\
\hline PSL LOC. 2 & A3100 & 0 & 1 & 1 & 1 & 3 \\
\hline PSL LOC. 3 & A3101 & 2 & 3 & 2 & 4 & 11 \\
\hline PSL LOC. 4 & A3102 & 1 & 2 & 1 & 1 & 5 \\
\hline PSL LOC. 5 & A3103 & 1 & 1 & 1 & 1 & 4 \\
\hline PSL LOC. 6 & A3210 & 0 & 0 & 0 & 2 & 2 \\
\hline RTL LOC. 1 & A3105 & 4 & 6 & 4 & 3 & 17 \\
\hline RTL LOC. 2 & A3106 & 4 & 7 & 4 & 5 & 20 \\
\hline RTL LOC. 3 & A3107 & 2 & 5 & 5 & 5 & 17 \\
\hline RTL LOC. 4 & A3108 & 2 & 3 & 2 & 1 & 8 \\
\hline RTL LOC. 5 & A3109 & 2 & 4 & 3 & 1 & 10 \\
\hline RTL LOC. 6 & A3110 & 2 & 3 & 1 & 1 & 7 \\
\hline Sigma V, LOC. 1 & A3186 & 0 & 0 & 0 & 1 & 1 \\
\hline Sigma V, LOC. 2 & A3187 & 0 & 1 & 0 & 2 & 3 \\
\hline Sigma V, LOC. 3 & A3188 & 0 & 1 & 0 & 1 & 2 \\
\hline Sigma V, LOC. 4 & A3189 & 1 & 0 & 0 & 1 & 2 \\
\hline Sigma V, LOC. 5 & A3190 & 0 & 0 & 0 & 4 & 4 \\
\hline Sigma V, LOC. 6 & A3191 & 0 & 0 & 1 & 2 & 3 \\
\hline
\end{tabular}




(a) - Multiply area TLD result by 0.23 to obtain dose estimates corrected for worker occupancy
(b) - Area TLD lost
(c) - Sample location not initiated yet
(d) - Sample location discontinued
(e) - Neutron dose from Hanford Standard Dosimeter
(f) - Neutron dose from Hanford Combination Neutron Dosimeter




\section{Distribution}

No. of

Copies

ONSITE

3 Fluor Hanford Company

RL Hill

L1-08

3 DOE Richland Operations Office

TL Aldridge

K8-50

R Briggs

E Parsons
No. of

Copies

35 Pacific Northwest National Laboratory

JL Allen

P7-78

SR Bivins (5)

P8-17

HJ Black-Kania

P7-28

FJ Bronson

P7-73

GD Buckley

P7-28

WT Buyers

P7-28

P7-78

P7-28

JR Christensen

P7-75

P7-78

P7-78

P7-78

P7-57

P7-78

P7-78

P7-60

P7-28

K4-13

P7-02

P8-95

P7-78

P7-78

GA Stoetzel (5)

K1-06

Distr. 1 